\title{
Vibrio coralliilyticus sp. nov., a temperature- dependent pathogen of the coral Pocillopora damicornis
}

\author{
Y. Ben-Haim, ${ }^{1}$ F. L. Thompson, ${ }^{2}$ C. C. Thompson, ${ }^{2}$ M. C. Cnockaert, ${ }^{2}$ \\ B. Hoste, ${ }^{2}$ J. Swings ${ }^{2}$ and E. Rosenberg ${ }^{1}$ \\ ${ }^{1}$ Department of Molecular Microbiology and Biotechnology, Tel Aviv University, Ramat Aviv, \\ Israel 69978 \\ ${ }^{2}$ Laboratory for Microbiology and BCCM ${ }^{T M} / L M G$ Bacteria Collection, Ghent University, \\ K. L. Ledeganckstraat 35, Ghent 9000, Belgium
}

Correspondence

E. Rosenberg eros@post.tau.ac.il

\begin{abstract}
Vibrio sp. YB1 ${ }^{\top}\left(=\right.$ ATCC BAA $-450^{\top}=$ LMG $20984^{\top}$ ), the aetiological agent of tissue lysis of the coral Pocillopora damicornis, was characterized as a novel Vibrio species on the basis of $16 \mathrm{~S}$ rDNA sequence, DNA-DNA hybridization data ( $\mathrm{G}+\mathrm{C}$ content is $45.6 \mathrm{~mol} \%)$, AFLP and $\mathrm{GTG}_{5}-\mathrm{PCR}$ genomic fingerprinting patterns and phenotypic properties, including the cellular fatty acid profile. The predominant fatty acids were $16: 0$ and $18: 1 \omega 7 \mathrm{c}$. The name Vibrio coralliilyticus sp. nov. is proposed for the novel coral-pathogenic species. In addition to strain $\mathrm{YB}^{\top}{ }^{\top}$, which was isolated from the Indian Ocean, five additional strains of $V$. coralliilyticus have been isolated, three from diseased $P$. damicornis in the Red Sea, one from diseased oyster larvae (Kent, UK) and one from bivalve larvae (Brazil). The six V. coralliilyticus strains showed high genotypic and phenotypic similarities and all were pathogenic to $P$. damicornis. The closest phylogenetic neighbours to V. coralliilyticus are Vibrio tubiashii, Vibrio nereis and Vibrio shilonii.
\end{abstract}

\section{INTRODUCTION}

During the last two decades, there has been a large increase in the frequency and distribution of coral diseases (HoeghGuldberg, 1999; Peters, 1997; Richardson, 1998). These diseases have altered both total abundance and species diversity (Loya et al., 2001). The causative agents of only a few of these diseases have been reported: bleaching of Oculina patagonica by Vibrio shilonii (Kushmaro et al., 1996, 1997), black band disease by a microbial consortium (Carlton \& Richardson, 1995), sea fan disease by Aspergillus sydowii (Smith et al., 1996; Geiser et al., 1998) and coral white plague possibly by a Sphingomonas sp. (Richardson et al., 1998). The aetiological agents of most coral diseases are presently unknown. What is known is that most, if not all, of the diseases occur at higher-than-normal sea-water temperatures (Rosenberg \& Ben-Haim, 2002; Hoegh-Guldberg, 1999). Since temperatures are expected to rise considerably during this century, it is likely that coral disease will become even more prevalent. Thus, there is an increasing need to identify and characterize coral pathogens.

Published online ahead of print on 26 July 2002 as DOI 10.1099/ ijs.0.02402-0.

The GenBank/EMBL/DDBJ accession numbers for the 16S rDNA sequences of strains LMG 10953, LMG 21349 and $\mathrm{YB} 1^{\top}$ are AJ316167, AJ440004 and AJ440005.
Recently, we isolated a novel temperature-dependent pathogen of the coral Pocillopora damicornis, tentatively named Vibrio sp. YB1. At water temperatures above $26{ }^{\circ} \mathrm{C}$, a pure culture of this pathogenic strain caused rapid destruction of the coral tissue within 2 weeks (Ben-Haim \& Rosenberg, 2002). The present study was carried out in order to characterize Vibrio sp. YB1 and related strains using a polyphasic approach.

\section{METHODS}

Micro-organisms, media and growth conditions. Strain $\mathrm{YB1}^{\mathrm{T}}$ $\left(=\right.$ ATCC BAA $\left.-450^{\mathrm{T}}=\mathrm{LMG} 20984^{\mathrm{T}}\right)$ was isolated from a diseased coral of the species $P$. damicornis in the Indian Ocean near Zanzibar, as described previously (Ben-Haim \& Rosenberg, 2002). Strains LMG 21348, LMG 21349 and LMG 21350 were isolated from three different diseased P. damicornis colonies on the Eilat coral reef, Red Sea. The bacteria were isolated from the crushed tissues of the corals, as described previously (Ben-Haim \& Rosenberg, 2002). V. shilonii ATCC BAA-91 ${ }^{\mathrm{T}}$ (=LMG $\left.19703^{\mathrm{T}}=\mathrm{DSM} 13774^{\mathrm{T}}\right)$ was isolated from a bleached coral of the species $O$. patagonica (Kushmaro et al., 1996, 2001). The other Vibrio strains used in this study were obtained from the BCCM/LMG Bacteria Collection (Table 1). Strains were grown routinely at $30{ }^{\circ} \mathrm{C}$ in MBT medium [1.8\% Marine broth (MB) 2216 (Difco), $0 \cdot 9 \% \mathrm{NaCl}, 0 \cdot 5 \%$ tryptone (Difco)], on MB 2216 agar ( $1.8 \%$ MB 2216, $0.9 \% \mathrm{NaCl}, 1.8 \%$ agar), tryptone soy agar (TSA; Oxoid) supplemented with $2 \% \mathrm{NaCl}$ or on TCBS (thiosulphate-citrate-bile salts-sucrose; Difco) agar adjusted to $3 \% \mathrm{NaCl}$. Liquid cultures were prepared in $125 \mathrm{ml}$ 
Table 1. Strains used in this study

\begin{tabular}{|c|c|}
\hline Strain(s) & Source and date of isolation \\
\hline $\mathrm{YB}^{\mathrm{T}}\left(=\right.$ ATCC BAA $\left.-450^{\mathrm{T}}=\mathrm{LMG} 20984^{\mathrm{T}}\right)$ & Diseased coral (P. damicornis), Zanzibar, Tanzania, 1999 \\
\hline LMG 10953 (=NCIMB 2165) & Diseased oyster (C. gigas) larvae, Kent, UK, 1980s \\
\hline LMG $20538(=$ INCO 83 $)$ & Bivalve (N. nodosus) larvae, LCMM Florianópolis, Brazil, 1998 \\
\hline V. nereis LMG $3895^{\mathrm{T}}\left(=\operatorname{ATCC} 25917^{\mathrm{T}}\right)$ & Sea water, Hawaii, USA \\
\hline V. mediterranei LMG $11258^{\mathrm{T}}\left(=\mathrm{CIP} 10320^{\mathrm{T}}\right)$ & Coastal sea water, Valencia, Spain \\
\hline V. shilonii LMG $19703^{\mathrm{T}}\left(=\right.$ ATCC BAA-91 $\left.{ }^{\mathrm{T}}=\mathrm{DSM} 13774^{\mathrm{T}}\right)$ & Bleached coral, Tel Aviv, Israel, 1995 \\
\hline
\end{tabular}

flasks containing $10 \mathrm{ml} \mathrm{MBT}$, incubated with shaking (160 r.p.m.) for $24-48 \mathrm{~h}$. Cultures were stored either at $-70{ }^{\circ} \mathrm{C}$ in $15 \%$ glycerol or as lyophilized cells.

DNA isolation and genomic fingerprinting (FAFLP, BOXPCR, GTG $\mathbf{5}$-PCR). Bacterial DNA was extracted following the technique of Pitcher et al. (1989). Fluorescent amplified fragment length polymorphism (FAFLP) patterns were generated and analysed as described previously (Thompson et al., 2001). Briefly, $1 \mu \mathrm{g}$ highmolecular-mass DNA was digested with TaqI and HindIII, followed by ligation of restriction-half-site-specific adaptors to all restricted fragments. Subsequently, two PCR amplifications were applied using primers H00/T00 and H01-6FAM/T03. Separation of the PCR products was done on $36 \mathrm{~cm}$ denaturing polyacrylamide gels on an ABI Prism 377 DNA sequencer (Applied Biosystems). Tracking and normalization of the lanes were performed by the GeneScan 3.1 software (Applied Biosystems). Normalized tables of peaks, containing fragments of 50-536 bp, were analysed with BioNumerics 2.0 software (Applied Maths). Similarity among band patterns was calculated using the Dice similarity coefficient and dendrograms were built using the Ward algorithm (Sneath \& Sokal, 1973).

Rep-PCR fingerprinting using GTG $_{5}$ and BOX primers was performed as described previously (Rademaker et al., 1998). Briefly, PCRs consisted of $1 \mu \mathrm{l}$ template DNA $\left(50 \mathrm{ng} \mu^{-1}\right), 5 \mu \mathrm{l} 5 \times$ Gitschier buffer, $0 \cdot 4 \mu \mathrm{lBSA}\left(10 \mathrm{mg} \mathrm{ml}^{-1}\right), 2 \cdot 5 \mu \mathrm{DMSO}\left(10 \mathrm{mg} \mathrm{ml}^{-1}\right), 1 \cdot 25 \mu \mathrm{l}$ of a dNTP mixture (100 mM of each), $1 \mu \mathrm{GTG}_{5}$ primer or $1 \mu \mathrm{l} \mathrm{BOX}$ primer (both $0 \cdot 3 \mu \mathrm{g}^{-1}$; Amersham Pharmacia Biotech) and $0 \cdot 4 \mu \mathrm{l}$ Taq DNA polymerase $\left(5 \mathrm{U} \mathrm{\mu l}^{-1}\right.$; Goldstar Red). The PCR products generated with the $\mathrm{GTG}_{5}$ primer were electrophoresed in a $1.5 \%$ agarose gel $(\mathrm{w} / \mathrm{v})$ and $1 \times$ TAE buffer at a constant $55 \mathrm{~V}$ for $900 \mathrm{~min}$ at $4{ }^{\circ} \mathrm{C}$. The PCR products generated with the BOX primer were electrophoresed in a $2 \%$ agarose gel $(w / v)$ and $1 \times$ TBE buffer at a constant $130 \mathrm{~V}$ for $222 \mathrm{~min}$ at $4{ }^{\circ} \mathrm{C}$. After staining with ethidium bromide, the digitized patterns were normalized and analysed numerically using the software BioNumerics 2.0. Similarity among patterns was calculated based on Pearson's similarity coefficient and dendrograms were built using UPGMA (Sneath \& Sokal, 1973).

165 rDNA sequencing. Almost-complete $16 \mathrm{~S}$ rDNA sequences were obtained following the methodology described previously (Thompson et al., 2001). Briefly, fragments of the 16S rDNA were amplified by PCR using the conserved primers pA (16F27) and $\mathrm{pH}$ (16R1522) or MH1 (16F27) and MH2 (16R1485). Subsequently, purified products were used as templates for sequencing amplification using the ABI Prism BigDye Terminator Ready Reaction mix and eight primers (16F358, 16F536, 16F926, 16F1112, 16F1241, 16R339, 16R519 and 16R1093). Purified sequencing products were run on $48 \mathrm{~cm}$ denaturing polyacrylamide gels on an ABI Prism 377 DNA sequencer. Sequences were assembled with the AutoAssembler software (Applied Biosystems). The consensus sequences were transferred into BioNumerics 2.0 software, where a phylogenetic tree was constructed based on the neighbour-joining method (Saitou \& Nei, 1987). The phylogenetic positions of the consensus sequences were obtained using the program FASTA (Pearson \& Lipman, 1988) and compared to known Vibrio $16 \mathrm{~S}$ rDNA sequences (Dorsch et al., 1992; Ruimy et al., 1994; Mellado et al., 1996; Denner et al., 2002).

DNA-DNA hybridization experiments and $\mathbf{G}+\mathbf{C}$ content determination. DNA-DNA hybridization was performed under stringent conditions using the microplate technique (Ezaki et al., 1989) with photobiotin-labelled DNA at $39^{\circ} \mathrm{C}$ for $3 \mathrm{~h}$ as described previously (Willems et al., 2001). Hybridization values are means of the reciprocal and non-reciprocal values, each of which was performed in four replicates. The $\mathrm{G}+\mathrm{C}$ content of DNA was determined by HPLC (Tamaoka \& Komagata, 1984).

Phenotypic characterization. Colony morphology was examined using a stereoscopic microscope. Cell morphology was examined by scanning electron microscopy (JEOL 840A). Exponentially growing bacteria in MBT medium were adhered to a carbon-coated grid and negatively stained with $1 \%$ uranyl acetate. Classical phenotypic tests were performed by standard methods (Farmer \& Hickman-Brenner, 1992). Biochemical tests were performed using the API 20NE system (micromethod tests for the identification of non-enteric Gramnegative rods; bioMérieux). The standard API 20NE protocol was used except that media were adjusted to $3 \% \mathrm{NaCl}$. $\mathrm{NaCl}$ tolerance was determined in MBT medium containing varying concentrations (1-15\%) of $\mathrm{NaCl}$. Sensitivity to the vibriostatic compound O/129 (2,4-diamino-6,7-diisopropylpteridine; Sigma) was determined after incubation for $48 \mathrm{~h}$ at $30^{\circ} \mathrm{C}$ on $\mathrm{MB}$ agar containing $30 \mu \mathrm{g}$ of the compound on a disc.

Sensitivity to antibiotics was examined using either the minimal inhibition concentration (MIC) method, for erythromycin $\left(24 \mu \mathrm{g} \mathrm{ml}^{-1}\right)$, tetracycline $\left(20 \mu \mathrm{g} \mathrm{ml}^{-1}\right)$, chloramphenicol $\left(6 \mu \mathrm{g} \mathrm{ml}^{-1}\right)$ and kanamycin $\left(50 \mu \mathrm{g} \mathrm{ml}^{-1}\right)$, or by the paper disc method, for penicillin $\left(10 \mu \mathrm{g} \mathrm{disc}^{-1}\right)$ and ampicillin $\left(10 \mu \mathrm{g} \mathrm{disc}^{-1}\right)$. Growth was also tested on MB agar containing $200 \mu \mathrm{g}$ gentamicin $\mathrm{ml}^{-1}$.

Carbon utilization tests were carried out using Biolog GN2 MicroPlates. Pure cultures (12-18 h growth) were harvested from $\mathrm{MB}$ agar plates and suspended in $20 \mathrm{ml}$ GN/GP inoculating fluid (Biolog), adjusted to $3 \% \mathrm{NaCl}$, to an $\mathrm{OD}_{600}$ of $0 \cdot 130-0 \cdot 143$. The suspension was then distributed into Biolog GN2 microwell plates. Each plate contained 96 microwells with one of 95 different carbon sources in each and tetrazolium violet as an indicator of metabolic activity. The plates were incubated for $48 \mathrm{~h}$ at $30^{\circ} \mathrm{C}$. Wells that changed to purple were marked as positive for metabolic utilization. Fatty acid analysis was performed following the protocol of the 
Microbial Identification System (Microbial ID Inc.) as described previously (Huys et al., 1994). Strains for analysis were grown on TSA for $48 \mathrm{~h}$ at $28^{\circ} \mathrm{C}$.

The ability of each strain to infect the coral $P$. damicornis in controlled aquarium experiments was examined as described previously (Ben-Haim \& Rosenberg, 2002).

\section{RESULTS}

Strain $\mathrm{YB}^{\mathrm{T}}$ is a Gram-negative, motile, rod-shaped bacterium $(1.2-1.5 \times 0.8 \mu \mathrm{m})$ that has a single polar, sheathed flagellum (Fig. 1). These properties, together with its ability to form yellow colonies on TCBS agar and its sensitivity to the vibriostatic compound $\mathrm{O} / 129$, suggest that $\mathrm{YB}^{\mathrm{T}}$ represents a species of the genus Vibrio (Farmer \& Hickman-Brenner, 1992). The 16S rDNA sequences of strains $\mathrm{YB1}^{\mathrm{T}}$ (1465 bp; accession no. AJ440005), LMG 21349 (1468 bp; AJ440004) and LMG 10953 (1468 bp; AJ316167) were allocated to the $\gamma$-Proteobacteria using the FASTA program. These Vibrio strains formed a tight cluster, with more than $99 \% 16 \mathrm{~S}$ rDNA similarity (Fig. 2). Their closest phylogenetic neighbours were Vibrio tubiashii (97.2\%), Vibrio nereis $(96 \cdot 8 \%)$ and $V$. shilonii $(96 \cdot 6 \%)$.

AFLP, BOX-PCR and GTG5-PCR analysis revealed that the strains possess typical genomes, respectively consisting of $102 \pm 7,19 \pm 3$ and $23 \pm 2$ bands (Fig. 3). The inner AFLP and $\mathrm{GTG}_{5}-\mathrm{PCR}$ pattern similarities were higher than $64 \%$. It has recently been shown that AFLP and rep-PCR similarities around $65 \%$ represent more than $70 \%$ DNA-DNA

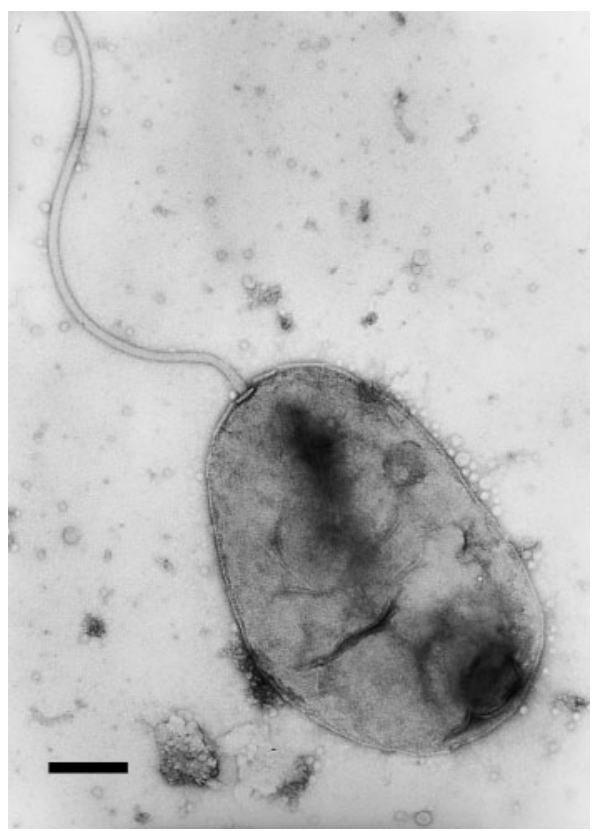

Fig. 1. Electron micrograph of a negatively stained cell of strain $\mathrm{YB}^{\top}{ }^{\top}$. Bar, $0.2 \mu \mathrm{m}$.

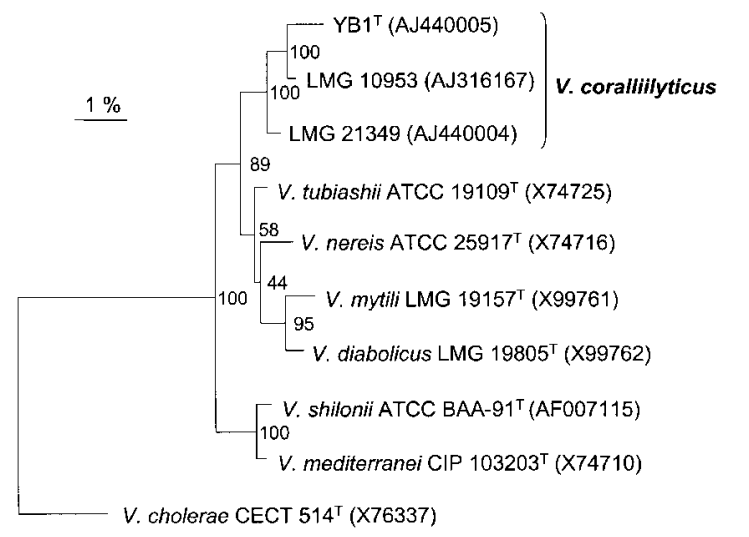

Fig. 2. Phylogenetic tree showing the relationships between $V$. coralliilyticus sp. nov. and other representative type strains of the genus Vibrio, based on the neighbour-joining method with almost-complete $16 \mathrm{~S}$ rDNA sequences. Bootstrap percentages after 1000 simulations are shown. Bar, 1\% estimated sequence divergence.

similarity (Rademaker et al., 2000). It was clearly demonstrated by the three fingerprinting methodologies that the six Vibrio isolates form a tight genomic group that is distinguishable from all other closely related Vibrio species. Surprisingly, strains $\mathrm{YB1}^{\mathrm{T}}$ and LMG 21350 showed very similar patterns by AFLP and $\mathrm{GTG}_{5}-\mathrm{PCR}$, although $\mathrm{YB1}^{\mathrm{T}}$ originated from the Indian Ocean and LMG 21350 from the Red Sea. Overall, the strains have less than $40 \%$ pattern similarity towards their closest phylogenetic neighbours analysed by the three fingerprinting methodologies.

DNA-DNA hybridization data (Table 2) confirmed that the six isolates form a single genomic group, with DNA-DNA similarities higher than $85 \%$. DNA-DNA similarity to $V$. nereis and $V$. tubiashii was respectively only 31 and $27 \%$. DNA-DNA similarities to V. shilonii, Vibrio diabolicus and Vibrio mytili were lower than $24 \%$. The G $+\mathrm{C}$ content of their DNA ranged from $44 \cdot 9$ to $45 \cdot 6 \mathrm{~mol} \%$.

The novel species conforms to the description of the family Vibrionaceae and of the genus Vibrio (Farmer \& HickmanBrenner, 1992). The cellular fatty acid compositions of the six novel strains are presented in Table 3. The novel strains had similar overall fatty acid profiles, congruent with those known for the family Vibrionaceae (Bertone et al., 1996; Urdaci et al., 1990). Differences in biochemical tests and carbon compound utilization between the six isolates are shown in Table 4. Of the 117 tests performed, the strains gave the same qualitative result in 110 cases. Strains $\mathrm{YB1}^{\mathrm{T}}$ and LMG 21350 gave identical results in all 117 phenotypic tests, although $\mathrm{YB} 1^{\mathrm{T}}$ was isolated from the Indian Ocean and LMG 21350 from the Red Sea. The other strains differed from $\mathrm{YB}^{\mathrm{T}}$ in only one to five of the 117 tests performed.

Strains of the novel species can be differentiated easily from their closest phylogenetic neighbours (Table 5). For 

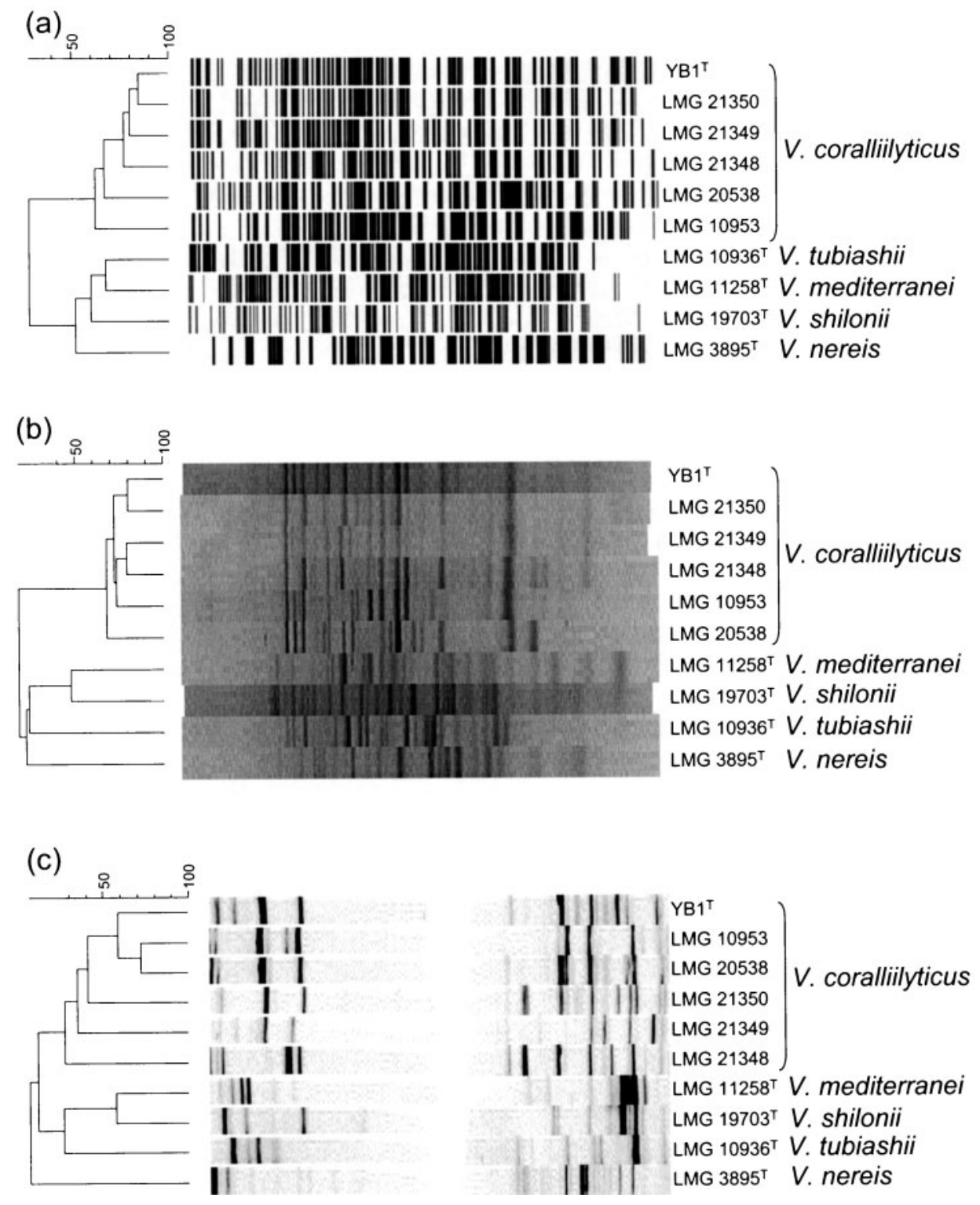

Fig. 3. (a) AFLP, (b) BOX and (c) $\mathrm{GTG}_{5}$ clustering analysis of $V$. coralliilyticus sp. nov. $(n=6)$ and its closest phylogenetic neighbours.

Table 2. DNA similarity among strains of $V$. coralliilyticus sp. nov., V. nereis and V. tubiashii

Values for DNA similarity are means $\pm \mathrm{SD}$ of reciprocal DNA-DNA hybridization experiments.

\begin{tabular}{|c|c|c|c|c|c|c|c|}
\hline \multirow[t]{2}{*}{ Strain } & \multirow[t]{2}{*}{$\mathrm{G}+\mathrm{C}$ content $(\mathrm{mol} \%)$} & \multicolumn{6}{|c|}{ DNA-DNA hybridization (\%) with: } \\
\hline & & 1 & 2 & 3 & 4 & 5 & 6 \\
\hline \multicolumn{8}{|l|}{$V$. coralliilyticus sp. nov. } \\
\hline 1. $\mathrm{YB1}^{\mathrm{T}}\left(=\mathrm{LMG} 20984^{\mathrm{T}}\right)$ & $45 \cdot 6$ & 100 & & & & & \\
\hline 2. LMG 20538 & $45 \cdot 1$ & $86 \pm 6$ & 100 & & & & \\
\hline 3. LMG 10953 & $44 \cdot 9$ & $98 \pm 13$ & $97 \pm 5$ & 100 & & & \\
\hline 4. LMG 21349 & $45 \cdot 6$ & $87 \pm 1$ & $88 \pm 3$ & $89 \pm 1$ & 100 & & \\
\hline 5. V. nereis $\mathrm{LMG} 3895^{\mathrm{T}}$ & $45 \cdot 6$ & $27 \pm 5$ & $31 \pm 2$ & $30 \pm 4$ & $30 \pm 6$ & 100 & \\
\hline 6. V. tubiashii LMG $10936^{\mathrm{T}}$ & $45 \cdot 7$ & $26 \pm 3$ & $27 \pm 3$ & $26 \pm 3$ & $26 \pm 5$ & $25 \pm 1$ & 100 \\
\hline
\end{tabular}


Table 3. Fatty acid profiles of strains of $V$. coralliilyticus sp. nov.

Values are percentages of total fatty acids.

\begin{tabular}{|lrccccc|}
\hline Fatty acid & YB1 $^{\text {T }}$ & LMG 21348 & LMG 21349 & LMG 21350 & LMG 10953 & LMG 20538 \\
\hline $12: 0$ & $2 \cdot 2$ & $3 \cdot 4$ & $3 \cdot 8$ & $3 \cdot 8$ & $2 \cdot 8$ & $3 \cdot 6$ \\
$12: 0$ 3-OH & $2 \cdot 7$ & $3 \cdot 1$ & $3 \cdot 9$ & $3 \cdot 7$ & $2 \cdot 0$ & $2 \cdot 8$ \\
$13: 0$ iso & $2 \cdot 6$ & $2 \cdot 3$ & $2 \cdot 6$ & $2 \cdot 4$ & $2 \cdot 8$ & $1 \cdot 7$ \\
$14: 0$ & $6 \cdot 5$ & $8 \cdot 1$ & $7 \cdot 8$ & $8 \cdot 3$ & $6 \cdot 9$ & $8 \cdot 5$ \\
$14: 0$ iso & $0 \cdot 5$ & $0 \cdot 2$ & $0 \cdot 3$ & $0 \cdot 2$ & $0 \cdot 7$ & $0 \cdot 8$ \\
$15: 0$ & $1 \cdot 3$ & $1 \cdot 8$ & $2 \cdot 0$ & $1 \cdot 9$ & $1 \cdot 8$ & $2 \cdot 8$ \\
$15: 0$ iso & $2 \cdot 8$ & $1 \cdot 1$ & $1 \cdot 3$ & $1 \cdot 5$ & $2 \cdot 3$ & $1 \cdot 0$ \\
$15: 0$ iso 3-OH & $1 \cdot 7$ & $1 \cdot 3$ & $1 \cdot 5$ & $1 \cdot 4$ & $1 \cdot 1$ & $0 \cdot 6$ \\
$16: 0$ & $14 \cdot 1$ & $15 \cdot 2$ & $14 \cdot 0$ & $15 \cdot 5$ & $14 \cdot 6$ & $16 \cdot 5$ \\
$17: 0$ & $2 \cdot 0$ & $2 \cdot 6$ & $3 \cdot 0$ & $2 \cdot 4$ & $\mathrm{v} 2 \cdot 5$ & $2 \cdot 8$ \\
$17: 0$ iso & $3 \cdot 2$ & $1 \cdot 7$ & $1 \cdot 8$ & $2 \cdot 0$ & $2 \cdot 4$ & $0 \cdot 9$ \\
$17: 1 \omega 8 c$ & $1 \cdot 3$ & $1 \cdot 7$ & $2 \cdot 1$ & $1 \cdot 7$ & $1 \cdot 6$ & $2 \cdot 1$ \\
$18: 1 \omega 7 c$ & $18 \cdot 2$ & $20 \cdot 6$ & $18 \cdot 0$ & $18 \cdot 6$ & $19 \cdot 1$ & $14 \cdot 5$ \\
\hline
\end{tabular}

instance, the isolates utilized D-serine, while V. tubiashii, $V$. nereis and $V$. shilonii do not. Furthermore, the isolates utilized $m$-inositol, methyl $\beta$-D-glucoside, $\alpha$-ketobutyric acid and alaninamide, whereas $V$. tubiashii and $V$. nereis do not. In contrast to the novel species, $V$. shilonii is negative for utilization of D-gluconic acid, L-leucine and D-serine. Moreover, the novel species possesses larger amounts of the fatty acids 17:0 and 17:0 iso than do V. tubiashii and $V$. nereis and larger amounts of $17: 0$ and $18: 1 \omega 7 c$ than does V. shilonii.

Because of the high genotypic and phenotypic similarities between the six novel Vibrio isolates, we examined the ability of each isolate to infect the coral $P$. damicornis in controlled aquarium experiments. All six strains were pathogenic, causing similar tissue damage within 2 weeks at $29{ }^{\circ} \mathrm{C}$, whereas $P$. damicornis corals infected with $V$. shilonii under similar experimental conditions remained healthy.

\section{DISCUSSION}

Vibrio sp. $\mathrm{YB}^{\mathrm{T}}$ has been reported to be the aetiological agent of tissue damage to the coral $P$. damicornis (Ben-Haim \& Rosenberg, 2002). From the data presented here, the strain clearly represents a novel Vibrio species. During the course of this investigation, three additional pathogenic Vibrio strains (LMG 21348, LMG 21349, LMG 21350) were isolated from diseased $P$. damicornis in the Red Sea and two other

Table 4. Differences in biochemical tests and carbon compound utilization between strains of $V$. coralliilyticus sp. nov.

All strains show the following properties: oxidase- and catalase-positive; acid is produced from glucose; nitrate is reduced to nitrite; indole is produced; positive reactions for $\beta$-glucosidase, $\beta$-galactosidase and gelatinase; urease-negative; utilize D- and L-alanine, L-histidine, hydroxyproline, L-ornithine, L-proline, D-serine, thymidine, D-mannitol, L-aspartic acid, L-histidine, $\alpha$-aminobutyric acid, D-galactose, methyl succinate, D-gluconic acid, succinic acid, bromosuccinic acid, alaninamide, L-serine, L-threonine, uridine, glycerol, glucose 6-phosphate, dextrin, glycogen, DL- $\alpha$-glycerol phosphate, Tweens 40 and 80, $\mathrm{N}$-acetylglucosamine, D-fructose, maltose, D-mannose, D-psicose, sucrose, L-alanyl glycine, L-asparagine, L-glutamic acid, glycyl L-aspartic acid and glycyl L-glutamic acid; susceptible to O/129, erythromycin, tetracycline, chloramphenicol and gentamicin; resistant to kanamycin, ampicillin and penicillin; growth in 1-7\% NaCl; no growth in the absence of $\mathrm{NaCl}$ or in the presence of $\geqslant 8 \% \mathrm{NaCl}$. Except for the tests included in the table, all six strains gave the same qualitative results with the API-20 NE system and Biolog GN2 MicroPlate tests.

\begin{tabular}{|c|c|c|c|c|c|c|}
\hline Characteristic & $\mathrm{YB1}^{\mathrm{T}}$ & LMG 10953 & LMG 20538 & LMG 21348 & LMG 21349 & LMG 21350 \\
\hline Arginine dehydrolase & + & - & - & - & - & + \\
\hline \multicolumn{7}{|l|}{ Utilization of: } \\
\hline Citrate & + & + & + & + & - & + \\
\hline Methyl $\beta$-D-glucoside & - & - & - & + & + & - \\
\hline Propionic acid & + & + & + & + & - & + \\
\hline Methyl pyruvate & + & + & + & - & + & + \\
\hline Glucose 1-phosphate & + & + & + & + & - & + \\
\hline D-Mannitol & + & - & + & + & + & + \\
\hline
\end{tabular}


Table 5. Differentiating phenotypic features of $V$. coralliilyticus sp. nov. and the most closely related species

Fatty acid methyl ester (FAME) analyses included six strains of $V$. coralliilyticus sp. nov., four of $V$. tubiashii, two of $V$. nereis and five of $V$. shilonii. Values are means $\pm \mathrm{SD}$ expressed as percentages of total fatty acids. Phenotypic data for V. nereis and V. tubiashii were obtained from Holt et al. (1994). v, Variable.

\begin{tabular}{|c|c|c|c|c|}
\hline Feature & V. coralliilyticus & V. tubiashii & V. nereis & V. shilonii \\
\hline \multicolumn{5}{|l|}{ Utilization of: } \\
\hline Cellobiose & - & + & - & + \\
\hline D-Galactose & + & + & - & + \\
\hline$m$-Inositol & + & - & - & $\mathrm{V}$ \\
\hline Methyl $\beta$-D-glucoside & + & - & - & + \\
\hline Acetic acid & + & - & $\mathrm{V}$ & + \\
\hline cis-Aconitic acid & + & - & + & + \\
\hline D-Gluconic acid & + & + & + & - \\
\hline$\beta$-Hydroxybutyric acid & - & $\mathrm{V}$ & + & $\mathrm{V}$ \\
\hline$\alpha$-Ketobutyric acid & + & - & - & $\mathrm{V}$ \\
\hline Alaninamide & + & - & - & + \\
\hline L-Histidine & + & - & $\mathrm{V}$ & + \\
\hline Hydroxy-L-proline & + & - & + & + \\
\hline L-Leucine & + & - & + & - \\
\hline D-Serine & + & - & - & - \\
\hline \multicolumn{5}{|l|}{ Fermentation of: } \\
\hline Amygdalin & - & + & + & + \\
\hline Melibiose & - & $\mathrm{V}$ & - & $\mathrm{V}$ \\
\hline Growth on $8 \% \mathrm{NaCl}$ & - & $\mathrm{V}$ & + & $\mathrm{V}$ \\
\hline \multicolumn{5}{|l|}{ FAME composition: } \\
\hline $17: 0$ & $2 \cdot 6 \pm 0 \cdot 3$ & $0 \cdot 5 \pm 0 \cdot 6$ & $1 \cdot 2 \pm 1 \cdot 1$ & $0 \cdot 2 \pm 0 \cdot 0$ \\
\hline $17: 0$ iso & $2 \cdot 0 \pm 0 \cdot 8$ & $0 \cdot 0$ & $0 \cdot 4 \pm 0 \cdot 5$ & $4 \cdot 2 \pm 2 \cdot 1$ \\
\hline $17: 1 \omega 8 c$ & $1 \cdot 8 \pm 0 \cdot 3$ & $1 \cdot 0 \pm 1 \cdot 4$ & $2 \cdot 7 \pm 2 \cdot 8$ & $0 \cdot 6 \pm 0 \cdot 6$ \\
\hline $18: 1 \omega 7 c$ & $18 \cdot 2 \pm 2 \cdot 0$ & $21 \cdot 6 \pm 5 \cdot 2$ & $21 \cdot 6 \pm 1 \cdot 5$ & $12 \cdot 1 \pm 1 \cdot 9$ \\
\hline
\end{tabular}

strains, LMG 20538 and LMG 10953, present in the BCCM/ LMG Bacteria Collection, were also shown to be closely

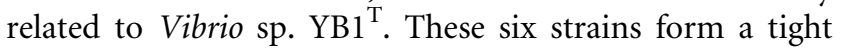
cluster, based on genotypic and phenotypic properties, that is significantly different from other Vibrio species. Based on these results, we propose the name Vibrio coralliilyticus sp. nov. for this novel pathogenic species.

One of the most interesting findings of this study was the demonstration of the power of bacterial taxonomy to uncover novel coral-pathogenic strains. Vibrio strains LMG 10953 and LMG 20538, respectively isolated from diseased larvae of Crassostrea gigas and Nodipecten nodosus, were shown to be pathogenic to the coral P. damicornis. Strain LMG 10953 was previously identified as V. tubiashii (Hada et al., 1984). Our results clearly demonstrate that this strain belongs to $V$. coralliilyticus sp. nov.

The fact that coral-pathogenic strains of $V$. coralliilyticus are widely distributed is important in understanding the source of coral disease and attempts to prevent their spread. $V$. coralliilyticus sp. nov. infects and causes tissue damage to its host coral only at water temperatures above $25^{\circ} \mathrm{C}$. It is likely that during the winter, when temperatures are lower, the bacterium is present in different hosts, possibly bivalve larvae. Clearly, the taxonomic studies described here open new and unexpected avenues of investigation regarding the transmission of coral diseases.

\section{Description of Vibrio coralliilyticus sp. nov.}

Vibrio coralliilyticus (co.ral.li.i.ly'ti.cus. L. n. corallium coral; Gr. adj. lytikos dissolving; N.L. adj. coralliilyticus coral-dissolving).

Conforms to the descriptions of the family Vibrionaceae and of the genus Vibrio (Farmer \& Hickman-Brenner, 1992). Cells are Gram-negative, non-spore-forming rods $(1.2-1.5 \times 0.8 \mu \mathrm{m})$ that are motile by a single polar, sheathed flagellum when grown on solid or liquid medium. Colonies are cream-coloured on marine agar and yellow on TCBS agar after $48 \mathrm{~h}$ incubation at $30^{\circ} \mathrm{C}$, have smooth edges and do not luminesce. The predominant cellular fatty acids are $16: 0$ and $18: 1 \omega 7 c$. Biochemical tests and carbon compound utilization data are summarized in Table 4 . The type strain, strain $\mathrm{YB}^{\mathrm{T}}$ (=LMG $20984^{\mathrm{T}}=$ ATCC BAA$450^{\mathrm{T}}$ ), was isolated from a diseased coral of the species Pocillopora damicornis in the Indian Ocean. Further strains have been isolated from diseased $P$. damicornis in the Red Sea and from larvae of oysters in the Atlantic Ocean. All six strains described here are pathogenic to the coral 
P. damicornis. The $\mathrm{G}+\mathrm{C}$ content of the type strain is $45 \cdot 6 \mathrm{~mol} \%$.

\section{ACKNOWLEDGEMENTS}

This work was supported in part by the Pasha Gol Chair for Applied Microbiology and the Israel Center for the Study of Emerging Diseases. J. S. has a personnel grant from the Fund for Scientific Research (FWO), Belgium. F. L. T. has a PhD scholarship (no. 2008361/98-6) from the Conselho Nacional de Desenvolvimento Científico e Tecnológico (CNPq), Brazil.

\section{REFERENCES}

Ben-Haim, Y. \& Rosenberg, E. (2002). A novel Vibrio sp. pathogen of the coral Pocillopora damicornis. Mar Biol 141, 47-55.

Bertone, S., Giacomini, M., Ruggiero, C., Piccarolo, C. \& Calegari, L. (1996). Automated systems for identification of heterotrophic marine bacteria on the basis of their fatty acid composition. Appl Environ Microbiol 62, 2122-2132.

Carlton, R. G. \& Richardson, L. L. (1995). Oxygen and sulfide dynamics in a horizontally migrating cyanobacterial mat: black band disease of corals. FEMS Microbiol Ecol 18, 155-162.

Denner, E. B. M., Vybiral, D., Fischer, U. R., Velimirov, B. \& Busse, H.-J. (2002). Vibrio calviensis sp. nov., a halophilic, facultatively oligotrophic $0.2 \mu \mathrm{m}$-filterable marine bacterium. Int J Syst Evol Microbiol 52, 549-553.

Dorsch, M., Lane, D. \& Stackebrandt, E. (1992). Towards a phylogeny of the genus Vibrio based on 16S rRNA sequences. Int J Syst Bacteriol 42, 58-63.

Ezaki, T., Hashimoto, Y. \& Yabuuchi, E. (1989). Fluorometric deoxyribonucleic acid-deoxyribonucleic acid hybridization in microdilution wells as an alternative to membrane filter hybridization in which radioisotopes are used to determine genetic relatedness among bacterial strains. Int J Syst Bacteriol 39, 224-229.

Farmer, J. J., III \& Hickman-Brenner, F. W. (1992). The genera Vibrio and Photobacterium. In The Prokaryotes, 2nd edn, pp. 2952-3011. Edited by A. Balows, H. G. Trüper, M. Dworkin, W. Harder, K. H. Schleifer. Heidelberg: Springer.

Geiser, D. M., Taylor, J. W., Ritchie, K. B. \& Smith, G. W. (1998). Cause of sea fan death in the West Indies. Nature 394, 137-138.

Hada, H. S., West, P. A., Lee, J. V., Stemmler, J. \& Colwell, R. R. (1984). Vibrio tubiashii sp. nov., a pathogen of bivalve mollusks. Int J Syst Bacteriol 34, 1-4.

Hoegh-Guldberg, O. (1999). Climate change, coral bleaching and the future of the world's coral reefs. Mar Freshw Res 50, 839-866.

Holt, J. G., Krieg, K. R., Sneath, P. H. A., Staley, J. T. \& Williams, S. T. (1994). In Bergey's Manual of Determinative Bacteriology, 9th edn, pp. 190-274. Edited by J. G. Holt. Baltimore: Williams \& Wilkins.

Huys, G., Vancanneyt, M., Coopman, R., Janssen, P., Falsen, E., Altwegg, M. \& Kersters, K. (1994). Cellular fatty acid composition as a chemotaxonomic marker for the differentiation of phenospecies and hybridization groups in the genus Aeromonas. Int J Syst Bacteriol 44, 651-658.

Kushmaro, A., Loya, Y. \& Rosenberg, E. (1996). Bacterial infection and coral bleaching. Nature 380, 396.

Kushmaro, A., Rosenberg, E., Fine, M. \& Loya, Y. (1997). Bleaching of the coral Oculina patagonica by Vibrio AK-1. Mar Ecol Prog Ser 147, 159-165.
Kushmaro, A., Banin, E., Loya, Y., Stackebrandt, E. \& Rosenberg, E. (2001). Vibrio shiloi sp. nov., the causative agent of bleaching of the coral Oculina patagonica. Int J Syst Evol Microbiol 51, 1383-1388.

Loya, Y., Sakai, K., Yamazato, K., Nakano, Y., Sambali, H. \& van Woesik, R. R. (2001). Coral bleaching: the winners and the losers. Ecol Lett 4, 122-131.

Mellado, E., Moore, E. R. B., Nieto, J. J. \& Ventosa, A. (1996). Analysis of 16S rRNA gene sequences of Vibrio costicola strains: description of Salinivibrio costicola gen. nov., comb. nov. Int J Syst Bacteriol 46, 817-821.

Pearson, W. R. \& Lipman, D. J. (1988). Improved tools for biological sequence comparison. Proc Natl Acad Sci U S A 85, 2444-2448.

Peters, E. C. (1997). Diseases of coral-reef organisms. In Life and Death of Coral Reefs, pp. 114-139. Edited by C. Birkeland. New York: Chapman \& Hall.

Pitcher, D. G., Saunders, N. A. \& Owen, R. J. (1989). Rapid extraction of bacterial genomic DNA with guanidium thiocyanate. Lett Appl Microbiol 8, 151-156.

Rademaker, J. L. W., Louws, F. J. \& de Brujin, F. J. (1998). Characterization of the diversity of ecologically important microbes by rep-PCR genomic fingerprinting. In Molecular Microbial Ecology Manual, pp. 3.4.3.1-3.4.3.27. Edited by A. D. L. Akkermans, J. D. van Elsas \& F. J. de Bruijn. Dordrecht: Kluwer.

Rademaker, J. L. W., Hoste, B., Louws, F. J., Kersters, K., Swings, J., Vauterin, L., Vauterin, P. \& de Bruijn, F. J. (2000). Comparison of AFLP and rep-PCR genomic fingerprinting with DNA-DNA homology studies: Xanthomonas as a model system. Int J Syst Evol Microbiol 50, 665-677.

Richardson, L. L. (1998). Coral diseases: what is really known? Trends Ecol Evol 13, 438-443.

Richardson, L. L., Goldberg, W. M. \& Kuta, K. G. (1998). Florida's mystery coral-killer identified. Nature 392, 557-558.

Rosenberg, E. \& Ben-Haim, Y. (2002). Microbial diseases of corals and global warming. Environ Microbiol 4, 318-326.

Ruimy, R., Breittmayer, V., Elbaze, P., Lafay, B., Boussemart, O., Gauthier, M. \& Christen, R. (1994). Phylogenetic analysis and assessment of the genera Vibrio, Photobacterium, Aeromonas, and Plesiomonas deduced from small-subunit rRNA sequences. Int J Syst Bacteriol 44, 416-426.

Saitou, N. \& Nei, M. (1987). The neighbor-joining method: a new method for reconstructing phylogenetic trees. Mol Biol Evol 4, 406-425.

Smith, G. W., Ives, L. D., Nagelkerken, I. A. \& Ritchie, K. B. (1996). Caribbean sea-fan mortalities. Nature 383, 487.

Sneath, P. H. \& Sokal, R. R. (1973). Numerical Taxonomy. San Francisco: W. H. Freeman.

Tamaoka, J. \& Komagata, K. (1984). Determination of DNAbase composition by reversed-phase high-performance liquidchromatography. FEMS Microbiol Lett 25, 125-128.

Thompson, F. L., Hoste, B., Vandemeulebroecke, K. \& Swings, J. (2001). Genomic diversity amongst Vibrio isolates from different sources determined by fluorescent amplified fragment length polymorphism. Syst Appl Microbiol 24, 520-538.

Urdaci, M. C., Marchand, M. \& Grimont, P. A. (1990). Characterization of 22 Vibrio species by gas chromatography analysis of their cellular fatty acids. Res Microbiol 141, 437-452.

Willems, A., Doignon-Bourcier, F., Goris, J., Coopman, R., de Lajudie, P., De Vos, P. \& Gillis, M. (2001). DNA-DNA hybridization study of Bradyrhizobium strains. Int $J$ Syst Evol Microbiol 51, 1315-1322. 